\title{
Fuat Ustakara
}

Gaziantep Üniversitesi, ustakara@gantep.edu.tr, Gaziantep-Türkiye

\section{AĞ TEKNOLOJİSININ GELİSIMIYLE KAMULARIN HALKLA İLİSKİLER İŞLEVSELLİĞİNE YÖNELIK ALGILARI: GAZIANTEP ARAŞTIRMASI}

\section{ÖZET}

Bu çalışma, kamuların halkla ilişkiler işlevselliğine dönük algılarını bir alan araştırmasıyla sorgulamayı amaçlamaktadır. Buna bağlı olarak, araştırma kapsamında Gaziantep kent merkezinde 564 kişilik bir örnekleme anket uygulanmaktadır. Araştırma bulgularında, halkla iliskilerin destekleyici bir rol üstlenerek örgüt yönetimleri açısından önemli bir fonksiyon olduğu belirlenmiştir. İkinci olarak, Gaziantep'teki halkla ilişkiler uygulamaları oldukça yetersiz görünmektedir. Üçüncü olarak, sosyal ağlar konusuna yönelerek halkla ilişkiler alanında hangi ağların sıklıkla kullanılması gerektiği önerilmektedir.

Anahtar Kelimeler: Halkla İlişkiler, Kamular, Medya, Sosyal Ağlar, Sistemler Yaklaşımı.

\section{THE PERCEPTIONS OF THE PUBLICS ABOUT THE FUNCTIONALITY OF PUBLIC RELATIONS WITH NETWORK TECHNOLOGY: THE RESEARCH OF GAZIANTEP}

\section{ABSTRACT}

The paper aims to interrogate the perceptions of the publics about the functionality of public relations with a fieldwork. Accordingly, the author conducts a survey with a sample of 564 people in the city centrum of Gaziantep within the fieldwork. The author determines that public relations is an important function by undertaking a supportive function for an organization's management in the research findings. Secondly, public relations applications particularly in Gaziantep seem inadequate. Thirdly, we suggest which networks you should use in public relations works by tending to social networks.

Keywords: Public Relations, Publics, Media, Social Networks, Systems Approach 


\section{GIRIŞ (INTRODUCTION)}

Günümüz işletmeciliğinin özellikle ABD'de ve Avrupa'da öne çıkan yönetsel faktörlerinden biri olarak halkla ilişkiler gösterilmektedir. Her ne kadar halkla ilişkiler uygulamaları ABD'de ve Batı Avrupa'da çok daha yoğun hissedilse de, Türkiye'de dahi öneminin fark edildiği düşünülebilir. Halkla ilişkiler, bir örgütte salt bir kişiye bağlı olarak yürütülen çalışmalar olarak konumlanmamaktadır. Halkla ilişkiler akademisinde yoğun ses getiren çalışmalarında, James Grunig ve Hunt (1984: 6), halkla ilişkileri bir örgüt ile o örgütün kamuları arasındaki iletişimin yönetimi olarak tanımlamaktadır. Dolayısıyla halkla ilişkiler uygulamalarının örgütsel bir süreç olduğu anlaşılmaktadır. Bu açıdan bakıldığında, sistemler yaklaşımı halkla ilişkiler işlevine bir değer katmaktadır. James Grunig, Larissa Grunig ve Ehling (1992:72), yönetimin örgütün dış kamularıyla iyi ilişkiler sürdürebilmesi için iletişim uzmanlarına güvendiklerini belirtir.

Halkla ilişkiler uygulamalarıyla, örgütün çalışma ve etkinliklerine ilişkin bilgiler paydaşlara ve kamulara iletilirken kitle iletişim araçlarından yararlanılması yoluna gidilir. Kamularla etkileşime geçilirken, bazen gazete ve dergiler gibi yazılı medyadan, bazen radyo ve televizyon gibi elektronik medyadan, bazen de sosyal ağlar yoluyla Web 2.0 teknolojilerinden bağlantı kurulur. Halkla ilişkiler uygulamalarının değişen çehresiyle örgütün çevresi gün geçtikçe genişlemekte ve bu geniş çevreye hızlı ve etkin bilgi aktarımının gerçekleşmesinde internet öne çıkmaktadır (Budak ve Budak, 2010: 278). Dolayısıyla dijital iletişim, örgütsel iletişimin gerek iç ve gerekse dış çevreyle daha verimli yönetilmesini olası kılmaktadır (Sayımer, 2008:64).

Halkla ilişkiler, yeni iletişim teknolojileriyle kamularla etkileşim boyutunu güçlendirmiş; geribildirim hızının yükselişine bağlı olarak işlevselliğini artırmıştır. Ağ, halkla ilişkilerin tasarım yaratıcılığını üst seviyeye taşımıştır. Bir örnek verilecek olursa, kamu kurumları bilgilendirmede çekici görsellerle dikkat çekmeyi başarırken; küresel piyasalara açılan bir marka, pazarına girdiği ülkenin toplumsal değerleriyle bütünleşerek mesajlarını iletebilmektedir. İmaj, örgütler açısından önemli bir gösterge olarak yorumlanabilir.

Kurumsal imaj, halkla ilişkiler çalışmalarının kamuların algılarını biçimlendirme yönüne karşılık gelmesiyle örgüte değer katan bir olgudur. Kurumsal imajı geliştirmenin başat öğelerinden biri, kurumsal sosyal sorumluluk (KSS) uygulamalarına yönelerek iyi bir izlenim bırakmaktır. Halkla ilişkilerin yirminci yüzyılda işlerlik kazanma nedenlerinden biri olarak kamu ve özel sektör örgütlerinin toplumsal sorumluluk duygularının güçlenmesi gösterilmektedir (Ertekin, 2000:18). Buna ek olarak, günümüzde pek çok şirket, yılıık bilançolarını ve raporlarını hazırlarken raporda kurumsal sosyal sorumluluk konusunda da faaliyet raporu düzenleme ve paydaşlarıyla paylaşma işine yönelmişlerdir (Ural, 2006:45).

Çalışma, üç temel bölümden oluşarak öncelikle iki kuramsal bölüm ve sonrasında bir araştırma bölümü olmak üzere yapılandırılmıştır. Birinci bölüm, halkla ilişkilerin stratejik boyutunu öne çıkararak işlevselliğini açıklamakta; halkla ilişkilere duyulan örgütsel gereksinimi ortaya koymaktadır. İkinci bölüm, halkla ilişkilere sistemler yaklaşımıyla bakışı getirmektedir. Burada birinci bölümdeki bilgilerin izdüşümünden açık sisteme yönelik bir uyarlama yapılmaktadır. Çalışmanın üçüncü bölümü, potansiyel kamular üzerinden halkla ilişkilere bakışı ölçmeye dönük olarak Gaziantep'te gerçekleştirilen bir alan araştırmasına dayanmaktadır. 


\section{2. ÇALIŞMANIN ÖNEMI (RESEARCH SIGNIFICANCE)}

Halkla ilişkiler, işletmeler açısından değerlendirildiğinde, çă̆ımızın gelişim gösteren yönetsel bir fonksiyonudur. Kamuların algılarını başarıyla yönetmek, halkla ilişkiler çalışmalarının başat işlevselliklerinden biri olarak öne çıkmaktadır. Yeni iletişim teknolojileri, örgütlerin halkla ilişkiler çalışmalarının kapasitesini artırmıştır. Web ağının olanaklarından yararlanma ve özellikle sosyal medya ağının akıcılığını kullanma, halkla ilişkilerin gücünü pekiştirmiştir. Sistemler yaklaşımı, halkla ilişkilerin örgütlerin destekleyici fonksiyonu olma pozisyonunu açıklama bağlamında önemli bir bakış getirmektedir.

Çalışma, halkla ilişkilerin Türkiye'de bir "sanayi şehri" olarak tanınan Gaziantep'teki imajını ve önemini anlamaya dönük olması yönüyle önemli bir konuya temas etmeyi amaçlamaktadır. Biraz daha açacak olursak, çalışma, potansiyel kamuların örgüt-kamu ilişkilerinde halkla ilişkiler işlevini nasıl algıladıklarını anlama, Gaziantep özelinde ve Türkiye genelinde kamu sektörü ve özel sektör kuruluşlarının halkla ilişkiler çalışmalarını ne düzeyde başarılı algıladıklarını öğrenme ve örgütlerin örgüt-kamu etkileşiminde hangi sosyal ağlara ağırlık vermeleri gerektiğini önerme bağlamında halkla ilişkiler literatürüne katkı sağlama yönüyle önem taşımaktadır.

\section{KAVRAMSAL ÇERÇEVE (THE CONCEPTUAL FRAMEWORK)}

Çalışmanın kavramsal çerçevesi iki temel bölümden oluşmaktadır: İlk önce, örgüt yönetimlerinde halkla ilişkiler işlevselliğine strateji odaklı bir bakış getirilmekte; bunun sonrasında halkla ilişkiler işlevi sistemler yaklaşımı çerçevesinden açıklanma yoluna gidilmektedir.

\subsection{Halkla İlişkilerin İşlevselliği (The Functionality of Public Relations)}

"İletişim" ve "yönetim" kavramlarının kesiştiği süreç, bilim, meslek ve sanat' olan halkla ilişkiler, işlevsel bağlamda geniş bir alanı kuşatmaktadır. Bu geniş alan; kurumsal imaj, algı yönetimi, sosyal sorumluluk, sorun yönetimi, itibar yönetimi, kriz yönetimi gibi birbiriyle bağlantılı ve birbirinden oldukça farklı uygulamalar bütünü olarak karşımıza çıkmaktadır (bkz. Kalender, 2008:30-37; Ural, 2006:16).

Halkla ilişkilerin işlevselliğini anlamak için öncelikle halkla ilişkiler uygulamalarının yöneldiği kamu² kavramına bakmak gerekir. Bernays (1935: 82), kamu kavramını açıklarken, kamunun çok önemli ve acil durumlarda birbirine bağlı ve birleşik mevcudiyette olabildiği gibi, bazı ortak çıkarlar etrafında toplanan daha küçük gruplar olarak oluşabileceğini de eklemektedir. Bir kamunun üyeleri, ortak bir şeye sahiptirler -aynı sorun veya konudan etkilenirler (Grunig and Hunt, 1984:143). Kamular, ortak sorunları deneyimleyen bireylerden oluşan bağlantısız sistemler olarak başlarlar; ama kolektif davranışa kalkışan örgütlenmiş ve güçlü aktivist gruplara dönüşebilirler (Grunig and Repper, 1992: 138). Burada üzerine basılması gereken husus; kamuların doğru tespit edilmesi, sorunların çözümü açısından oldukça önemli görünmektedir.

\footnotetext{
1 Halkla ilişkilerin anlamlandırılmasına dönük ayrıntılı bilgi için bkz. Geçikli, $1999: 251-263$

"Kamu" ile "paydaş" sözcükleri, genellikle birbiriyle karıştırılmaktadır. Bu açıdan bakıldığında, çeşitli kaynaklardan yararlanmak gerekir. Bir örgütün faaliyetlerinden doğrudan ve/veya dolaylı olarak etkilenen tüm kesimlere paydaş adı verilir (Aktan ve Börü, 2007:18). Daha farkında ve aktif olan paydaşlar, kamular olarak tanımlanabilir (Grunig and Repper, 1992:125).
} 
Kamuları anlamak ve farklı kamuların farkına varmak gerekir. Halkla ilişkiler yöneticileri, örgütlerinin ilgilenmesi gerektiği kamuların doğasını belirlemek için kamuların olası üyelerini araştırmalıdırlar (Grunig and Hunt, 1984: 147). Aslına bakılacak olursa, halkla ilişkilere bilimsel bir boyut kazandıran unsurlardan biri, araştırmaya dayalı olarak sorunlara/konulara ilişkin kamuların belirlenmesi olmaktadır. Dozier ve Ehling'in belirttiği gibi (1992:182), kısa dönemde kamuların bilgi, tutumlar ve davranışlarında anlamlı değişikliklerin elde edilmesi olası değildir.

Halkla ilişkiler, örgütün itibarının yönetimi olarak görülmekte (Ural, 2006:29); bu açıdan bakıldığında, strateji öne çıkmaktadır. Halkla ilişkilerin örgütleri daha etkili konuma getirebilmesi için stratejik olarak uygulanması gerekir (Grunig, 1992:12). Strateji; yaklaşım, tasarı, plan veya sistem anlamına gelmektedir (Grunig and Repper, 1992:123). Halkla ilişkiler çalışmaları, örgüte bir plan dahilinde yön vererek stratejik açıdan değerli konuma gelir.

Halkla ilişkiler ve strateji arasındaki sıkı bağı gösteren Görpe (2001:79), oluşturduğu halkla ilişkiler tanımında, "strateji doğrultusunda belirlenen amaçlara ulaşmak..." ifadesiyle stratejiyi halkla ilişkiler çalışmalarının merkezine yerleştirmektedir. Stratejik iletişim yönetimi kavramının halkla ilişkilere verilen alternatif isimlerden biri olduğuna dikkat çekilmekte (Çınarlı, 2013:6); dolayısıyla halkla ilişkilerin yönetsel açıdan önemine işaret edilmektedir.

Halkla ilişkiler bölümleri, üst yönetimi bilgilendirme amacına bağlı olarak üst yönetime, karar mercilerine yakın çalışmalı; örgütün paydaş ve kamularına iletmek istediği mesajların belirlenmesi ve aktarılması sürecinde etkin rol üstlenmelidirler (Paksoy, 1999: 25). İdeal olarak, halkla ilişkiler, planlama bölümüne ve üst düzey yöneticilere çevredeki paydaşlar hakkında girdi sağlayarak, stratejik yönetimin tamamlayıcı bir parçası olmalıdır (Grunig and Repper, 1992:121). Stratejik halkla ilişkiler, yönetimde halkla ilişkiler işlevinin etkin düzeyde olduğu örgütlerde uygulanabilir (Ural, 2006:14). Stratejik yönetilen halkla ilişkiler, bir örgütün en önemli paydaşlarıyla ilişkileri kurmak üzere tasarlanır (Grunig and Repper, 1992:123). Böylece örgüt-kamu ilişkileri halkla ilişkiler stratejileriyle mükemmelleştirilmek üzere biçimlendirilir.

Halkla ilişkiler uygulamalarının planlanması, yönetilmesi, değerlendirilmesi gerektiği yönündeki görüş, halkla ilişkilerin stratejik iletişim uygulamaları olduğunun göstergesidir (Ural, 2006:16). Buna göre, halkla ilişkiler, kamularla etkileşimi sağlayan bilimsel araştırmalara dayalı stratejik iletişim uygulamaları olarak anlaşılabilir.

\subsection{Sistemler Yaklaşımı ve Halkla İlişkiler (The Systems Approach and Public Relations)}

Sistemler yaklaşımı, örgütlere bütünsel bir bakış açısı getirmede önemli görünmektedir. Bu nedenle bu bölümde sistemler yaklaşımı içerisinde halkla ilişkiler işlevinin rolü açılmaya çalışılmaktadır.

Sistem kavramı, 1950'li ylllarda sosyal bilim alanında kullanılmaya başlamıştır (Sabuncuoğlu, 2001:11). Sistem kavramı, en genel anlamıyla, kendi aralarında ilişkili öğeler bütünü veya bir aradaki işlevler dizini olarak karşılık bulmaktadır (Yoldaş, 2004:62). Buradan hareketle, sistem kavramı, esas itibariyle bir bütünü anlatmakta; bütünün parçaları alt sistemler oluşturmakta ve bunlar arasında dinamik ilişkiler kurulmaktadır (Sabuncuoğlu, 2001:11). 
"Genel Sistem Kuramı" adlı eseri ile sistem kuramının temelini atan Ludwig von Bertalanffy", açık ve kapalı sistem ayrımına gider. Açık sistemler, sistemin dış çevresinden girdiler almakta ve çıktılarla yanıt vererek bundan bir yandan kendisi etkilenmekte, öte yandan toplumsal çevreyi etkilemektedir (Yoldaş, 2004:18). Açık sistemler, çevreyle sürekli gerçekleştirilen bir değişim halinde oldukları gibi (girdi-çıtı), gerekli bir koşul ortaya çıkmazsa da, bu değişme durumunda (dengeleşim) bütüncül bir denge durumuna erişebilirler (Pieczka, 2002:222). Sistem kuramında örgüt ile çevresi arasındaki dengeye işaret edilir. Parsons, diğer sistemler kuramcıları ile birlikte, örgüt ile çevresi arasındaki dengenin önemini vurgulamıştır (Grunig, 1992:468).

Örgütsel kuramcllar, günümüzde örgütlere "sistemler" olarak bakmaktadır. Bir sistem, etkileşimli bölümlerin veya alt sistemlerin örgütlenmiş bir ekibidir. Her bir alt sistem, bütün örgüt gibi diğer alt sistemleri etkilemektedir (Grunig and Hunt, 1984: 8). Bir başka deyişle, sistemler yaklaşımı, birbiriyle ilişkili alt sistemlerin oluşturduğu örgütsel bütünü ima ettiği için, herhangi bir alt sistemin performansı bütün sistemi etkileyecektir. Böylece halkla ilişkiler bölümü, yönetsel bir alt sistem olarak, herhangi bir örgütün başarısına veya başarısızlığına katkıda bulunmaktadır (Grunig, Grunig, and Ehling, 1992:72). Sistemler yaklaşımı, bir örgütü çevresindeki tehditlere ve firsatlara duyarlı bir organizma olarak kavrama eğilimindedir (Tarhan, 2008:140). Sözü edilen tehdit ve frrsatları örgüt yönetimine bildirmek görevi, esas itibariyle halkla ilişkiler işlevselliği içerisinde değerlendirilebilir. Bu görev, halkla ilişkileri stratejik açıdan değerli bir konuma getirmektedir.

Grunig ve Hunt (1984), sistemler yaklaşımı çerçevesinde halkla ilişkilerin örgüt yönetimindeki konumunu bir şekil aracılığıyla açıklama yoluna gitmişlerdir. Açıklayıcı niteliğine bağlı olarak, söz konusu şekli buraya almak yararlı görünmektedir.

Grunig ve Hunt (1984), aşağıdaki şekil aracılığıyla halkla ilişkileri bütün alt sistemler ile ilişkili ve yönetim alt sistemine doğrudan bağlı bir alt sistem olarak konumlandırmışlardır. Buradaki bakış açısından, örgütsel bir alt sistem olarak halkla ilişkilerin işlevsel boyutuna güç verildiği anlaşılmaktadır.

Somut bir örnek vermek gerekirse, uluslararası halkla ilişkiler ajanslarının faaliyet alanlarının yoğunluklu olarak artmasının nedeni, uluslararası şirketlerin farklı pazarlara yönelme ihtiyaçlarıyla doğru orantılı olmakta (Becerikli, 2005:38) ve sistemler yaklaşımına bağlı olarak, örgüt-çevre ilişkileri bağlamında halkla ilişkiler alt sisteminin işlevsel boyutunu açığa çıkarmaktadır.

Açık sistemler kuramı, halkla ilişkiler işlevinin bir örgütün uyarlama alt sistemi bağlamında kamuları dinamik olarak açıklayabileceğini belirtir (Dozier and Grunig, 1992:399). Halkla ilişkiler işlevinin kamuların dinamik yapısına dönük olarak örgüt yönetimini yönlendirmesi, halkla ilişkilerin stratejik açıdan öneminin bir boyutu olarak anlaşılabilir.

Yönetimin açık sistem tarzı çoğu örgüt için en iyi şekilde işlese de, çoğu örgüt bu sistemi kullanmaz. Çünkü baskın koalisyon ${ }^{4}$ kapalı sistem yaklaşımıyla gücünü daha kolay devam ettirebileceğine inanmaktadır (Robbins, 1990; aktaran: Grunig and Grunig, 1992:299).

\footnotetext{
3 Bertalanffy, genel sistem kuraminın ilk kuramsal temellerini 1920'li ve 1930'lu yıllarda geliştiren bir teorik biyologdur (ayrıntılı bilgi için bkz. Yoldaş, 2004:1215).

4 Baskın koalisyon, örgütlerdeki stratejik kararları alan yönetim kesimi için kullanılan bir terimdir (Ayrıntılı bilgi için bkz. Grunig, 1992:23-24).
} 
Aynı zamanda, baskın koalisyon, genellikle açık, simetrik bir sistemin gücünü tehdit edeceğine inanır (Grunig and Grunig, 1992:299-300). Böylece çoğu örgüt, kapalı sistem yaklaşımıyla hareket eder ve halkla ilişkiler işlevselliği ile çelişen bir kısırdöngüye girilir.

Halkla ilişkiler, açık sistem yaklaşımıyla örgütün kamularına açllan vitrini olarak örgüt-kamu ilişkilerini düzenleyici bir rol üstlenir. Bu nedenle, açık sistem işleyişindeki örgütler, halkla ilişkiler iletişimini güçlendirerek hareket ettiklerinde, sorunların yönetiminde yüksek performans düzeyine erişebilirler.

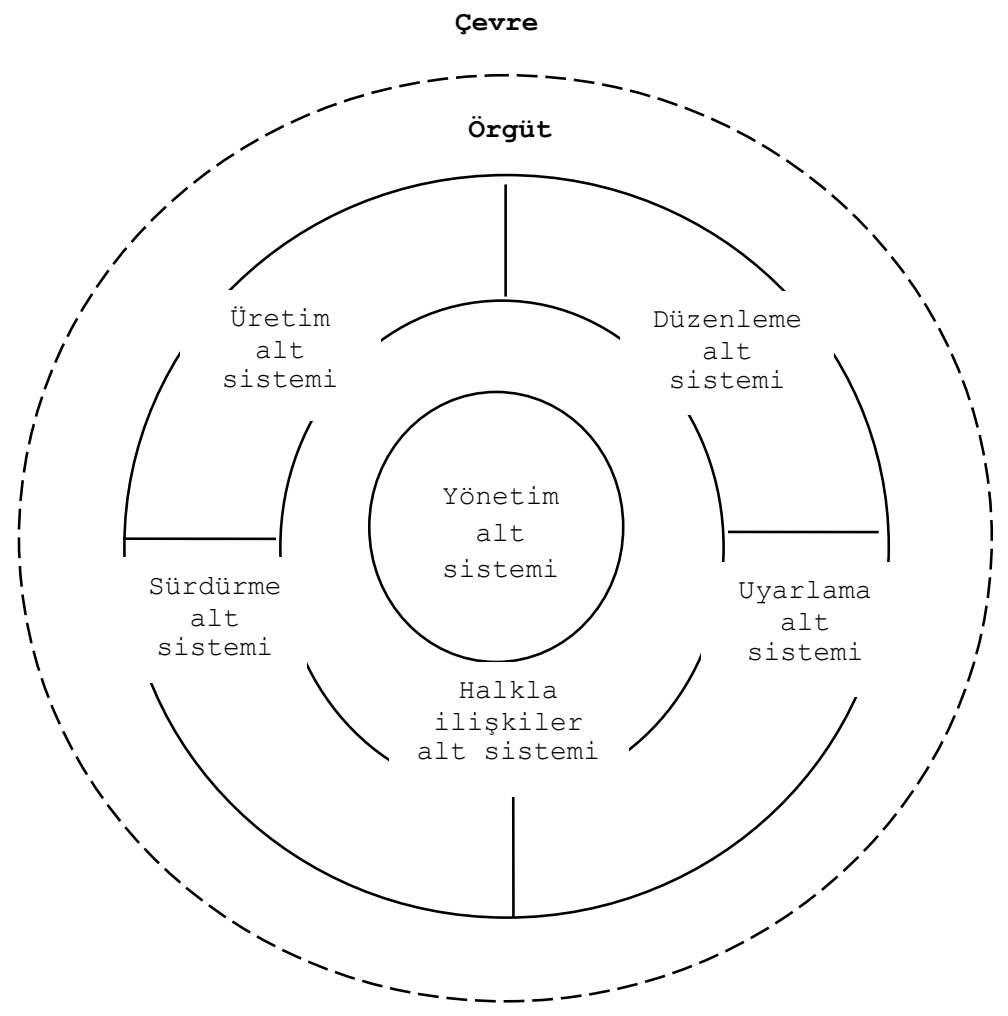

Kaynak: (Grunig and Hunt, 1984:9)

Şekil 1. Örgütsel Bir Alt Sistem Olarak Halkla İlişkiler (Figure 1. Public Relations as an Organizational Subsystem)

\section{ARAŞTIRMA (THE RESEARCH)}

Çalışmanın üçüncü bölümü, teorik düzlemi açacak bir araştırmaya dayanmaktadır. Bu bölümde problem durumu, araştırmanın amaç ve önemi, araştırmanın evren ve örneklemi, araştırmanın sınırlılıkları hakkında bilgi verilecek ve verilerin analizine geçilerek bölüm, bulguların yorumu ile sonuçlandırılacaktır.

\subsection{Problem Durumu (Problem Status)}

Halkla ilişkilerin önemi ve işlevselliği, Türkiye'de ABD ve Batı Avrupa ülkelerine görece geç fark edilmiş; halen halkla ilişkilerin rolü pek çok kişi ve yönetici nezdinde iletişim teknisyenliği ile sınırlandırılmış olmaktadır. Marka Şehir unvanıyla konumlanan Gaziantep gibi bir Sanayi Şehrinde bile ISO-500 Türkiye'nin En Büyük İsletmeleri sıralamasında yer alan pek çok işletmenin halkla ilişkiler biriminin mevcut olmaması, bu gerçekliğin en açık göstergesidir. Dolayısıla halkla ilişkilerin önem ve işlevselliğinin algılanma düzeyini öğrenmek, bu çalışmanın problem durumu olarak anlaşılabilir. 


\subsection{Araştırmanın Amacı ve Önemi}

\section{(Purpose and Importance of the Research)}

Araştırmanın temel amacı, halkla ilişkilere yönelik oluşan olumlu ve olumsuz algıları ve yönetsel açıdan halkla ilişkilerin işlevselliğine yönelik algıları temsil düzeyi yüksek bir araştırma ile saptamaktır. Araştırma, olası tüm paydaş ve kamuları kapsayacak şekilde toplumsal düzlemde halkla ilişkilerin nasıl algılandığını belirlemeye yönelik olmasıyla önem taşımaktadır.

\subsection{Araştırmanın Modeli (Model of the Research)}

Araştırma, deneme modellerinin uygulandığı ortamlardan biri olan alan araştırması olarak yapılandırılmıştır. Karasar (2005:104), deneme modellerinin genelde gerçekleştiği iki tür ortamdan birincisini laboratuvar, ikincisini alan olarak gösterir ve alanın doğal bir ortam olduğunu belirtir. Gerçekleştirilen araştırmada sayısal veri toplamak amacıyla anket tekniği uygulanmıştır. Kuş (2009: 44), anketlerin kişisel ifadelere dayalı inançlara ve davranışlara ilişkin araştırma sorularının bireylere yöneltilmesi için uygun bir yöntem olduğunu vurgular.

\subsection{Araştırmanın Evreni ve Örneklemi (Population and Sample of the Research)}

Araştırmanın evreni, Türkiye'nin ticaret ve sanayi anlamında önde gelen büyükşehirlerinden biri olan Gaziantep'tir. Gaziantep'in nüfusu en güncel veri olarak 2012-2013 yılı verilerine göre 1.844.438 kişi olarak saptanmıştır (Tüík, 23.11.2014).

Araştırmanın örneklemi, özel sektör veya kamu sektöründeki herhangi bir örgüt (şirket, kurum, kuruluş) için potansiyel kamu niteliğini taşıyan, Gaziantep'te yaşayan ve mesleki duruma göre geniş bir dağılım gösteren, basit tesadüfî örnekleme dayalı olarak seçilmiş katılımcılar olmaktadır.

\subsection{Araştırmanın Sınırlılıkları (Limitations of the Research)}

Araştırma, mekân olarak bir Sanayi Şehri olan Gaziantep'te gerçekleştirilmiştir. Yaş sınırlaması bağlamında, en alt düzey 18 yaş olarak belirlenmiş; konu olarak "halkla ilişkiler işlevselliğine yönelik algılar" kapsamıyla sınırlanmıştır. Araştırma, zaman dilimi açısından ele alınacak olursa, 2014 yılı Ağustos ayında, bir aylık süreçte gerçekleştirilmiştir.

\section{BULGULAR (FINDINGS)}

Araştırmadaki katılımcı sayısı 564'tür. Verilerin kategorize edilmesi şu şekildedir: Sosyo-demografik özelliklere göre dağılım, halkla ilişkilerin önemine ilişkin algılar, halkla ilişkiler iletişiminde iletişim araçlarının önemine ilişkin algılar, kitle iletişim araçlarının kullanılma sıklığı, sosyal medya platformlarını kullanım durumu, sosyal medya platformlarını kullanma sıklığı, en çok kullanılan sosyal medya kanalları.

Cinsiyete göre dağılıma bakıldığında \%59,8 (337 kişi) erkek, 40,2 (227 kişi) kadındır. Katılımcıların 53,4 (301 kişi) evli, 44,7 (252 kişi) bekâr iken o 1,9 (11 kişi) bu soruya yanıt vermemiştir.

Meslek gruplarına göre dağılım geniş bir ölçeğe yayılmaktadır. Verilere göre 으, (207 kişi) memur5, 20,6 (116 kişi) öğrenci, \%12,9 (73 kişi) iş̧̧i, 9 (51 kişi) esnaf, 6,7 (38 kişi) profesyonel meslek

\footnotetext{
5 Memur kategorisinde kamu kurumlarında çalışan öğretim elemanları, öğretmenler, polis, subay vb., kadrolu memurlar ve sözleşmeli memurlar alınmıştır.
} 
gruplarına ${ }^{6}$ mensup kişiler, 6,4 (36 kişi) ev hanımları, \%4, 1 (23 kişi) emekli, ㄴ,1 (6 kişi) işsiz ve \%0,2 (1 kişi) vakıf çalışanı olarak ayrılmaktadır. $13 \mathrm{kişi}(\% 2,3)$ bu soruya yanıt vermemiştir.

Yaş aralığına göre dağılımda 18-27 yaş arası 36 (203 kişi), 2837 yaş arası \%34,2 (193 kişi), 38-47 yaş arası 15,4 (87 kişi), 48-57 yaş arası ㄱ, 8 (44 kişi) ve 58 yaş ve üzerindekiler 6,6 (37 kişi) olmaktadır.

Eğitim durumuna göre dağılımda ilkokul/ilköğretim düzeyi 9,8

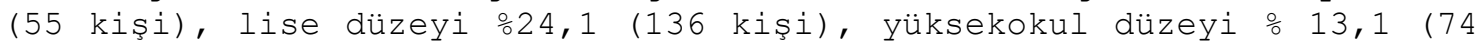
kişi), fakülte düzeyi \%42,2 (238 kişi), lisansüstü düzey \%9,4 (53 kişi) olarak gerçekleşmiştir. Cevapsızların oranı, ㄴ,4 (8 kişi) olmaktadır.

Gelir durumuna göre dağılımda geliri olmayanlar ${ }^{7}$ \%24,3 (137 kişi), asgari ücret düzeyinde geliri olanlar \%8,2 (46 kişi), 891-1500 TL geliri olanlar o19,1 (108 kişi), 1501-2250 TL geliri olanlar 017,2 (97 kişi), 2251-3000 TL geliri olanlar $\% 21,3$ (120 kişi) ve 3001 TL ve üzeri geliri olanlar o9,2 (52 kişi) şeklinde yansımaktadır. Bu soruya yanıt vermeyenlerin oranı, 익 (4 kişi) olmaktadır.

Tablo 1. Halkla ilişkilerin önemine ilişkin algılar

(Table 1. Perception on importance of public relations)

\begin{tabular}{|c|c|c|c|c|c|}
\hline Yargilar & $\mathrm{N}$ & Min. & Mak. & A.O. & Std.Sapma \\
\hline $\begin{array}{l}\text { Büyük şirketlerin halkla ilişkiler } \\
\text { birimleri olmalıdır. }\end{array}$ & 549 & 1,00 & 5,00 & 4,00 & 1,20 \\
\hline $\begin{array}{l}\text { Halkla ilişkiler çalışmaları kurumsal } \\
\text { imaj açısından önemsenmelidir. }\end{array}$ & 549 & 1,00 & 5,00 & 3,85 & 1,09 \\
\hline $\begin{array}{l}\text { Örgütlerin kurumsal imajı örgütün } \\
\text { geleceği açısından önemlidir. }\end{array}$ & 552 & 1,00 & 5,00 & 3,85 & 1,14 \\
\hline $\begin{array}{l}\text { Kurumsal web sitelerindeki tanıtıcı } \\
\text { bilgiler günümüz modern koşullarında } \\
\text { önemlidir. }\end{array}$ & 551 & 1,00 & 5,00 & 3,84 & 1,17 \\
\hline $\begin{array}{l}\text { Halkla ilişkilerin önemi yeni iletişim } \\
\text { teknolojileriyle birlikte artmlştır. }\end{array}$ & 554 & 1,00 & 5,00 & 3,84 & 1,11 \\
\hline $\begin{array}{l}\text { Kurumsal web sitelerinin tasarımı örgüt } \\
\text { yönetimlerince önemsenmelidir. }\end{array}$ & 554 & 1,00 & 5,00 & 3,82 & 1,12 \\
\hline $\begin{array}{l}\text { Sosyal sorumluluk örgütler açısından } \\
\text { önemli bir halkla ilişkiler } \\
\text { uygulamasıdır. }\end{array}$ & 540 & 1,00 & 5,00 & 3,79 & 1,12 \\
\hline $\begin{array}{l}\text { Halkla ilişkiler hem özel sektör } \\
\text { kuruluşları hem de kamu kurum ve } \\
\text { kuruluşları için önemli kazanımlar } \\
\text { sağlamaktadır. }\end{array}$ & 553 & 1,00 & 5,00 & 3,77 & 1,09 \\
\hline $\begin{array}{l}\text { Halkla ilişkiler örgütlerin çevrelerine } \\
\text { uyumunu sağlayan önemli bir destekleyici } \\
\text { fonksiyondur. }\end{array}$ & 553 & 1,00 & 5,00 & 3,76 & 1,04 \\
\hline $\begin{array}{l}\text { Halkla ilişkiler örgüt yönetimlerinin } \\
\text { önemli bir fonksiyonudur. }\end{array}$ & 552 & 1,00 & 5,00 & 3,73 & 1,20 \\
\hline $\begin{array}{l}\text { Halkla ilişkiler çalışmalarıyla örgütler } \\
\text { uzun vadeli düşünüldüğünde kaybettikleri } \\
\text { paradan daha fazlasını kazanmaktadır. }\end{array}$ & 554 & 1,00 & 5,00 & 3,62 & 1,12 \\
\hline $\begin{array}{l}\text { Halkla ilişkiler çalışmalarının örgütsel } \\
\text { çkarlar ile kamu yararını bir arada } \\
\text { gözettiğini düşünüyorum. }\end{array}$ & 557 & 1,00 & 5,00 & 3,33 & 1,13 \\
\hline
\end{tabular}

Halkla ilişkilerin önemine ilişkin algıların sorgulanmasında, büyük şirketlerin halkla ilişkiler birimlerinin olması gerekliliği

\footnotetext{
6 Profesyonel meslek grupları: Bu kategoriye mühendis, eczacı, avukat gibi mesleklerde toplananlar alınmıştır.

7 Geliri olmayanlar grubunu öğrenciler ve ev hanımları olușturmaktadır.
} 
(A.O.=4,00) birinci sıraya oturmuş; halkla ilişkiler çalışmalarının kurumsal imaj açısından önemsenmesi gerekliliği $(A .0 .=3,85)$ ve örgütlerin kurumsal imajının örgüt geleceği açısından önemli olduğu görüşü $(\mathrm{A} .0 .=3,85)$ ilk sıralarda yer almıştır. Sıralamadaki en son yargllar, halkla ilişkilerin örgüt yönetimlerinin önemli bir fonksiyonu olduğu $(\mathrm{A} .0 .=3,73)$, uzun vadeli düşünüldüğünde halkla ilişkiler çalışmalarıyla örgütlerin kaybettikleri paradan aslında daha fazlasını kazanacağı (A.O.=3,62) ve halkla ilişkiler uygulamalarının örgütsel çıkarlar ile kamu yararını bir arada gözettiği görüşü $(A .0 .=3,33)$ yer almaktadır.

Sosyo-demografik değişkenler ile Tablo l'deki bazı sorular arasında çeşitli açılardan anlamlılık ilişkileri sorgulanmıştır. Burada bu sorgulamaların sonuçları analiz edilecektir:

Mesleklere göre yapılan sorgulamada, halkla ilişkilerin örgüt yönetimlerinin önemli bir fonksiyonu olması görüşüne katılma düzeyinde anlamlı farklılıklar saptanmıştır. Bu yargıya katılma düzeyi bakımından profesyonel meslek grubu (A.0.=4,08), emekli (A.0.=3,95), memur (A.O.=3,93), ev hanımı (A.O.=3,82), esnaf (A.0.=3,68), işçi $(A .0 .=3,13)$ olarak sıralanmaktadır. Buna göre, işçiler ile memurlar arasında ve iş̧̧iler ile profesyonel meslek grubu mensupları arasında anlamlı farklılık ( $F=4,98 \mathrm{p}=$, 000$)$ olduğu görülmektedir.

Eğitim düzeyine göre sorgulamada, halkla ilişkilerin örgüt yönetimlerinin önemli bir fonksiyonu olması görüşüne katılma düzeyinde yine anlamlı farklılıklar saptanmıştır. Lisansüstü düzeyi (A.0.=4, 28), fakülte düzeyi (A.O.=3,91), yüksekokul düzeyi (A.0.=3,67), lise düzeyi (A.O.=3,40), ilkokul/ilköğretim düzeyi (A.0.=3,30) olarak yansımaktadır. Buna göre, ilkokul/ilköğretim düzeyi ile fakülte düzeyi ve ilkokul/ilköğretim düzeyi ile lisansüstü düzeyi arasında, lise düzeyi ile fakülte düzeyi ve lise düzeyi ile lisansüstü düzeyi arasında, yüksekokul düzeyi ile lisansüstü düzeyi arasında anlamlı farklılıklar $(F=8,59 \mathrm{p}=, 000)$ olduğu görülmektedir.

Gelir düzeyine göre sorgulamada, halkla ilişkiler çalışmalarıyla örgütler uzun vadeli düşünüldüğünde kaybettikleri paradan daha fazlasını kazanması görüşüne katılma düzeyinde anlamlı farklılıklar olduğu belirlenmiştir. Bu sorgulamada, gelirinin olmadığını bildirenlere ${ }^{8}$ yer verilmemiştir. Aylık ortalama 3001 TL ve üzeri geliri olanlar (A.O.=4,13), 1501-2250 TL arası geliri olanlar (A.0.=3,88), 2251-3000 TL arasi geliri olanlar (A.O.=3,59), asgari ücretliler (A.O.=3,44), 891-1500 TL geliri olanlar (A.O.=3,37) katılma düzeyinde seyretmektedir. Buna göre, asgari ücretliler ile 3001 TL ve üzeri geliri olanlar arasında, 891-1500 TL geliri olanlar ile 1501-2250 TL arası geliri olanlar arasında, 891-1500 TL geliri olanlar ile 3001 TL ve üzeri geliri olanlar arasında, 2251-3000 TL geliri olanlar ile 3001 TL ve üzeri geliri olanlar arasında anlamlı farklılıklar (F=5, 62 $\mathrm{p}=, 000$ ) olduğu görülmektedir.

Mesleklere göre yapılan sorgulamada, halkla ilişkiler çalışmalarının kurumsal imaj açısından önemsenmesi gerektiği görüşüne katılma düzeyinde anlamlı farklılıklar olduğu gözlenmiştir. Profesyonel meslek grubu mensupları (A.O.=4,13), emekliler $($ A.O.=4,09), memur kesimi (A.O.=3,99), esnaf (A.0.=3,84), öğrenciler $(\mathrm{A} .0 .=3,83)$, ev hanımları $(\mathrm{A} .0 .=3,75)$, işçiler $(\mathrm{A} .0 .=3,33)$ ortalamayla bu yargıya katılmaktadırlar. Buna göre, işçiler ile memurlar arasında, işçiler ile öğrenciler arasında ve işçiler ile profesyonel meslek grubu üyeleri arasında anlamlı farklılıklar ( $F=3,93 \mathrm{p}=, 001)$ olduğu görülmektedir.

\footnotetext{
8 Geliri olmayanlar, çoğunlukla ev hanımı ve öğrencilerden oluşmaktadır. Görüldüğü gibi, bu kesimlerde gelir durumu diğer kategorilerdeki katılımcılardan farklılık göstermektedir. Bu nedenle, bu kategoridekiler ölçümlemeye alınmamıştır.
} 
Yaş aralığına göre sorgulamada, halkla ilişkilerin öneminin yeni iletişim teknolojileriyle birlikte artması görüşüne katılma düzeyinde anlamıı farklılıklar saptanmıştır. 58 yaş ve üzeri (A.0.=4,24), 48-57 yaş arası (A.O.=4,20), 38-47 yaş arası (A.0.=4,00), 28-37 yaş arası $(\mathrm{A} .0 .=3,80), \quad 18-27$ yaş arası (A.O.=3,65) ortalama değerine sahiptirler. Buna göre, 18-27 yaş arası katılımcılar ile 48-57 yaş arası katılımcılar arasında ve 18-27 yaş arası katılımcılar ile 58 yaş ve üzerindeki katılımcllar arasında anlamlı farklılıklar (F=4,40 p=,002) olduğu görülmektedir.

Cinsiyete göre sorgulamada, halkla ilişkilerin örgüt yönetimlerinin önemli bir fonksiyonu olması görüşüne katılma düzeyinde anlamlı bir farklılık olmadığı belirlenmiştir. Bu yargıya katılım düzeyi, erkek katılımcılar $(\mathrm{A} .0 .=3,80)$ ve kadın katılımcılar $(\mathrm{A} .0 .=3,64)$ ortalamayla gerçekleşmektedir. Buna göre, erkek ve kadın katılımcılar arasında anlamlı bir farklılık ( F=5,50 p=, 128) olmadığı görülmektedir.

Medeni duruma göre sorgulamada, sosyal sorumluluğun örgütler açısından önemli bir halkla ilişkiler uygulaması olduğu görüşüne katılma düzeyinde anlamlı bir farklılık olmadığı belirlenmiştir. Bu yargıya katılım düzeyi, evli katılımcılarda (A.O.=3,84) ve bekâr katılımcılarda (A.O.=3,73) ortalama değerlerinde olmaktadır. Buna göre, evli ve bekâr katılımcılar arasında anlamlı bir farklılık $(\mathrm{F}=4,44 \mathrm{p}=$, 275) olmadığı görülmektedir.

Araştırmanın bir diğer bölümünde Gaziantep'teki ve Türkiye genelindeki halkla ilişkiler çalışmalarının ne kadar önemsendiği ve bu uygulamaların ne kadar başarılı olduğu yönündeki algılar sorgulanmaktadır. Aşağıdaki tabloda bunun yansımalarını görmek mümkündür:

Tablo 2. Gaziantep Özelinde ve Türkiye Genelinde Halkla İlişkilere Yönelik Genel Algılar

(Table 2. General Perception on Public Relations Specific to Gaziantep and Throughout Turkey)

\begin{tabular}{|c|c|c|c|c|c|}
\hline Yargılar & $\mathrm{N}$ & Min. & Mak. & A.O. & Std.Sapma \\
\hline $\begin{array}{l}\text { Türkiye'deki büyük firmaların halkla } \\
\text { ilişkiler çalışmalarını başarılı } \\
\text { buluyorum. }\end{array}$ & 557 & 1,00 & 5,00 & 3,08 & 1,09 \\
\hline $\begin{array}{l}\text { Türkiye'de özel sektörde halkla } \\
\text { ilişkiler çalışmalarının } \\
\text { önemsendiğini düşünüyorum. }\end{array}$ & 563 & 1,00 & 5,00 & 2,93 & 1,18 \\
\hline $\begin{array}{l}\text { Türkiye'deki kamu kurum ve } \\
\text { kuruluşlarında halkla ilişkiler } \\
\text { çalışmalarının önemsendiğini } \\
\text { düşünüyorum. }\end{array}$ & 557 & 1,00 & 5,00 & 2,86 & 1,14 \\
\hline $\begin{array}{l}\text { Gaziantep'teki büyük firmaların } \\
\text { halkla ilişkiler çalışmalarını } \\
\text { başarılı buluyorum. }\end{array}$ & 560 & 1,00 & 5,00 & 2,74 & 1,14 \\
\hline $\begin{array}{l}\text { Gaziantep'teki kamu kurum ve } \\
\text { kuruluşlarında halkla ilişkiler } \\
\text { çalışmalarının önemsendiğini } \\
\text { düşünüyorum. }\end{array}$ & 558 & 1,00 & 5,00 & 2,71 & 1,17 \\
\hline $\begin{array}{l}\text { Gaziantep piyasasında halkla } \\
\text { ilişkiler çalışmalarının } \\
\text { önemsendiğini düşünüyorum. }\end{array}$ & 559 & 1,00 & 5,00 & 2,58 & 1,13 \\
\hline
\end{tabular}

Gaziantep'te ve Türkiye genelinde halkla ilişkiler uygulamalarına dönük algılanma durumunda, Türkiye'deki büyük firmaların halkla ilişkiler çalışmalarının başarılı olduğu görüşü, en yüksek ortalama değere $(\mathrm{A} .0 .=3,08)$ sahipken; Gaziantep piyasasında 
halkla ilişkiler çalışmalarının önemsendiği görüşü, en düşük ortalama değere $(\mathrm{A} .0 .=2,58)$ sahip görünmektedir.

Tablo 3. Halkla ilişkiler iletişiminde iletişim araçlarının önemine ilişkin algılar

(Table 3. Perception on importance of media in the context of public relations communication)

\begin{tabular}{|l|l|l|l|l|l|}
\hline Yargılar & $\mathrm{N}$ & Min. & Mak. & A. 0. & $\begin{array}{l}\text { Std. } \\
\text { Sapma }\end{array}$ \\
\hline $\begin{array}{l}\text { Halkla ilişkiler çalışmalarında } \\
\text { interneti bir iletişim aracı olarak } \\
\text { kullanmanın önemli olduğunu düşünüyorum. }\end{array}$ & 560 & 1,00 & 5,00 & 3,98 & 1,11 \\
\hline $\begin{array}{l}\text { Halkla ilişkiler çlışmalarında sosyal } \\
\text { medyayı bir iletişim aracı olarak } \\
\text { kullanmanın önemli olduğunu düşünüyorum. }\end{array}$ & 559 & 1,00 & 5,00 & 3,93 & 1,15 \\
\hline $\begin{array}{l}\text { Halkla ilişkiler çalışmalarında } \\
\text { televizyonu bir iletş̧ aracı olarak } \\
\text { kullanmanın önemli olduğunu düsünüyorum. }\end{array}$ & 554 & 1,00 & 5,00 & 3,83 & 1,05 \\
\hline $\begin{array}{l}\text { Halkla ilişkiler çalışmalarında gazeteyi } \\
\text { bir iletişm aracı olarak kullanmanın } \\
\text { önemli olduğunu düşünüyorum. }\end{array}$ & 556 & 1,00 & 5,00 & 3,64 & 1,08 \\
\hline $\begin{array}{l}\text { Halkla ilişkiler çalışmalarında dergiyi } \\
\text { bir iletişim aracı olarak kullanmanın } \\
\text { önemli olduğunu düşünüyorum. }\end{array}$ & 559 & 1,00 & 5,00 & 3,54 & 1,03 \\
\hline $\begin{array}{l}\text { Halkla ilişkiler çalışmalarında radyoyu } \\
\text { bir iletişim aracı olarak kullanmanın } \\
\text { önemli olduğunu düşünüyorum. }\end{array}$ & 558 & 1,00 & 5,00 & 3,51 & 1,10 \\
\hline
\end{tabular}

Katılımcllara göre, halkla ilişkiler iletişiminde en önemli iletişim aracı internet $\left(\mathrm{A} . \mathrm{O}_{.}=3,98\right)$ iken, hemen ardından sosyal medya $(M=3,93)$ gelmektedir. Tabloya bakıldığında, önem düzeyi düşük iletişim mecraları olarak dergi $(\mathrm{A} .0 .=3,54)$ ve radyo (A.O.=3,51) görülmektedir.

Katılımcıların kitle iletişim araçlarını kullanma durumu çeşitli sorular eşliğinde sorgulanmaktadır. Kitle iletişim araçları kullanım sıklığına göre yapılan sınıflandırma aşă̆ıdaki gibidir:

Tablo 4. Katılımcıların kitle iletişim araçları kullanım sıklığı (Table 4. Frequency of media use for the respondents)

\begin{tabular}{|c|c|c|c|c|c|c|c|c|c|c|c|c|}
\hline \multirow[t]{2}{*}{ KİA } & \multicolumn{2}{|c|}{$\begin{array}{c}\text { Hiç } \\
\text { kullanmam }\end{array}$} & \multicolumn{2}{|c|}{$0-2$ saat } & \multicolumn{2}{|c|}{ 2-4 saat } & \multicolumn{2}{|c|}{$4-6$ saat } & \multicolumn{2}{|c|}{$\begin{array}{l}6 \text { saat ve } \\
\text { üzeri }\end{array}$} & \multicolumn{2}{|c|}{ Cevapsız } \\
\hline & $F$ & $\frac{\circ}{0}$ & $F$ & $\frac{\circ}{0}$ & $\mathrm{~F}$ & $\frac{\circ}{0}$ & $\mathrm{~F}$ & $\frac{\circ}{0}$ & $F$ & $\frac{\circ}{0}$ & F & $\%$ \\
\hline Gazete & 171 & 30,3 & 316 & 56,0 & 53 & 9,4 & 13 & 2,3 & 9 & 1,6 & 2 & 0,4 \\
\hline Dergi & 319 & 56,6 & 201 & 35,6 & 24 & 4,3 & 8 & 1,4 & 7 & 1,2 & 5 & 0,9 \\
\hline TV & 53 & 9,4 & 196 & 34,8 & 186 & 33,0 & 69 & 12,2 & 56 & 9,9 & 4 & 0,7 \\
\hline Radyo & 225 & 39,9 & 245 & 43,4 & 55 & 9,8 & 28 & 5,0 & 7 & 1,2 & 4 & 0,7 \\
\hline Inter. & 52 & 9,2 & 140 & 24,8 & 136 & 24,1 & 130 & 23,1 & 105 & 18,6 & 1 & 0,2 \\
\hline
\end{tabular}

Kitle iletişim araçlarının kullanım sıklığına bakıldığında, katılımcıların kitle iletişim araçlarını hiç kullanmama durumunda, sırasıyla dergi 56,6 (319 kişi), radyo \%39,9 (225 kişi), gazete 30,3 (171 kiş), televizyon 9,4 (53 kişi) ve internet 9,2 (52 kisi) olarak yer edinmektedir. Kitle iletişim araçlarını 6 saat ve üzeri süreyle kullanma durumunda, sırasıyla internet o18,6 (105 kişi), televizyon ㅇ, 9 (56 kişi), gazete 1,6 (9 kişi), dergi ve radyo \%1,2 oranıyla (7 kişi) yer almaktadır. 
Tablo 5. Katılımcıların sosyal medya kullanım oranları

(Table 5. Rates of the respondents' social media use)

\begin{tabular}{|l|c|c|}
\hline Yargı & Frekans & $\frac{\circ}{\circ}$ \\
\hline Evet & 482 & 85,5 \\
\hline Hayır & 82 & 14,5 \\
\hline Toplam & 564 & 100,0 \\
\hline
\end{tabular}

Sosyal medya kullanımına dönük sorgulamada, katılımcıların 이, 5'i (482 kişi) sosyal medyayı kullandıklarını, o14,5'i (82 kişi) hiçbir sosyal medya aracını kullanmadıklarını belirtmişlerdir.

Tablo 6. Katılımcıların sosyal medya kullanım sıklığı

(Table 6. Frequency of the respondents' social media use)

\begin{tabular}{|c|c|c|c|c|c|c|c|c|c|c|}
\hline \multirow{2}{*}{ KIA } & \multicolumn{2}{|c|}{$0-2$ saat } & \multicolumn{2}{c|}{$2-4$ saat } & \multicolumn{2}{c|}{$4-6$ saat } & \multicolumn{2}{c|}{$\begin{array}{c}\text { saat ve } \\
\text { üzeri }\end{array}$} & \multicolumn{2}{c|}{ Cevapsız } \\
\cline { 2 - 10 } & Kişi & $\circ$ & Kişi & $\frac{\circ}{\circ}$ & Kişi & $\circ$ & Kişi & $\circ$ & Kişi & $\frac{\circ}{\circ}$ \\
\hline $\begin{array}{c}\text { Sosyal } \\
\text { medya }\end{array}$ & 188 & 39,0 & 123 & 25,5 & 99 & 20,6 & 71 & 14,7 & 1 & 0,2 \\
\hline
\end{tabular}

Sosyal medyayı kullanan katılımcllardan sosyal medyaya ayırdıkları zamanı o39'u (188 kişi) 0-2 saat, 이, 5'i (123 kişi) 2-4 saat arası, 20,6'sı (99 kişi) 4-6 saat arası, o14,7'si (71 kişi) 6 saat ve üzeri olarak bildirmişlerdir. Sosyal medya kullanıcılarının o0,2'sı (1 kişi) bu sorgulamaya yanıt vermemiştir.

Tablo 7. Katılımcıların en çok kullandıkları sosyal medya aracı

(Table 7. Commonly used social network for the respondents)

\begin{tabular}{|l|r|r|}
\hline Sosyal ağ & Frekans & \multicolumn{1}{|c|}{$\%$} \\
\hline Facebook & 320 & 66,4 \\
\hline Google Plus & 56 & 11,6 \\
\hline YouTube & 41 & 8,5 \\
\hline Twitter & 33 & 6,8 \\
\hline Instagram & 22 & 4,6 \\
\hline Diğerleri & 6 & 1,3 \\
\hline Cevapsız & 4 & 0,8 \\
\hline Toplam & 482 & 100,0 \\
\hline
\end{tabular}

Katılımcıların en çok kullandıkları sosyal medya araçları; sırasıyla Facebook 66,4 (320 kişi), Google Plus \%11,6 (56 kişi), YouTube 8,5 (41 kişi), Twitter $\% 6,8$ (33 kişi), Instagram \%4,6 (22 kişi) olarak gerçekleşmiştir.

Tablo 8. Katılımcıların ikinci en çok kullandığı sosyal medya aracı

(Table 8. Second used social network for the respondents)

\begin{tabular}{|l|c|c|}
\hline Sosyal ağ & Frekans & $\frac{\circ}{\circ}$ \\
\hline YouTube & 170 & 35,3 \\
\hline Twitter & 81 & 16,8 \\
\hline Facebook & 67 & 13,9 \\
\hline Google Plus & 64 & 13,3 \\
\hline Instagram & 54 & 11,2 \\
\hline Diğerleri & 9 & 1,9 \\
\hline İkinci sosyal medya kanalı kullanmayanlar & 32 & 6,6 \\
\hline Cevapsız & 5 & 1,0 \\
\hline Toplam & 482 & 100,0 \\
\hline
\end{tabular}

Katılımcıların ikinci en çok kullandıkları sosyal medya araçlarına bakıldığında; sırasıyla YouTube ㅇ, 3 (170 kişi), Twitter \%16,8 (81 kişi), Facebook \%13,9 (67 kişi), Google Plus \%13,3 (64 kişi), Instagram o11,2 (54 kişi) öne çıkmaktadır. İkinci bir sosyal 


paylaşım ağı kullanmayan katılımcı oranı 6,6 (32 kişi) olarak
yansımıştır.

Tablo 9. Katılımcıların üçüncü en çok kullandığı sosyal medya aracı (Table 9. Third used social network for the respondents)

\begin{tabular}{|l|c|c|}
\hline Sosyal ağ & Frekans & $\frac{\circ}{\circ}$ \\
\hline YouTube & 124 & 25,7 \\
\hline Google Plus & 70 & 14,5 \\
\hline Twitter & 66 & 13,7 \\
\hline Instagram & 60 & 12,5 \\
\hline Facebook & 44 & 9,1 \\
\hline Diğerleri & 23 & 4,8 \\
\hline Üçüncü sosyal medya kanalı kullanmayanlar & 94 & 19,5 \\
\hline Cevapsız & 1 & 0,2 \\
\hline Toplam & 482 & 100,0 \\
\hline
\end{tabular}

Katılımcıların üçüncü en çok kullandıkları sosyal medya araçları sırasıyla YouTube 025,7 (124 kişi), Google Plus \%14,5 (70 kişi), Twitter o13,7 (66 kişi), Instagram 12,5 (60 kişi), Facebook ○9,1 (44 kişi) şeklinde olmaktadır. Üçüncü bir sosyal paylaşım ağı kullanmayan katılımcı oranı, 이,5 (94 kişi) olarak görünmektedir.

\section{BULGULARIN YORUMU (DISCUSSION OF THE FINDINGS)}

Araştırmanın sosyo-demografik değişkenler boyutu, aşağıda görüleceği üzere heterojen bir nitelik içermektedir (bkz. Sosyodemografik dağılım). Halkla ilişkilerin önemine ilişkin algılara bakıldığında, büyük şirketlerin halkla ilişkiler biriminin olması gerektiği görüşü en yüksek değere sahip olmakta; buradan halkla ilişkilerin serbest piyasa ekonomisinin önemli bir öğesi olduğu çıkarımı yapılabilmektedir. Kurumsal imaja ilişkin iki yargı, aynı ortalama değerler ile ilk üçe yerleşirken, halkla ilişkiler işlevinin kurumsal imaj boyutunun önemsendiği görülmektedir. Yargılar içerisinde ă̆ teknolojisinin önemi dört ila altıncı sıralarda yer almaktadır. Buna göre, katılımcllar, genel itibariyle yeni iletişim teknolojilerini halkla ilişkiler işlevselliği açısından değerli olarak algılamaktadırlar. Sosyal sorumluluk, sekizinci sırada yine yüksek sayılabilecek bir ortalama değere sahiptir. Halkla ilişkilerin işlevselliği, sekiz ila onuncu sıralarda art arda toplanarak $($ A.O.=3,70) değerlerini aşan rakamları yakalamıştır. Sistemler yaklaşımı açısından bakıldığında, halkla ilişkilerin örgüt-çevre ilişkilerinin destekleyici bir fonksiyonu olarak önemli bir alt sistem olduğu görüşü ağırlık kazanmaktadır. Halkla ilişkilerin ekonomik kazanım sağlamasına yönelik algıların sorgulandığı yargıya katılma durumu on birinci sırada yer almaktadır. Katılımcıların değerlendirmeleri, biraz kuşkulu görünse de yine de halkla ilişkilerin uzun vadede maddi açıdan kaybettirdiği paradan daha çoğunu kazandırdığı yönündedir. Bu kategorideki sorgulamanın en sonunda, halkla ilişkilerin çift yönlü yarar sağladığı görüşü yer almaktadır. Buna göre, katılımcılar, halkla ilişkiler çalışmalarındaki amacın karşılıklı yarar olduğu görüşüne temkinli yaklaşmaktadırlar. Katılımcilar, her ne kadar sosyal sorumluluğu önemli bir halkla ilişkiler uygulaması olarak görse de, buna görece halkla ilişkiler uygulamalarındaki karşılıklı çıkar anlayışına biraz daha kuşkulu bir bakış açısına sahip görünmektedirler (bkz. Tablo 1).

Katılımcıların meslekleri açısından, halkla ilişkilerin gerek özel sektör ve gerekse kamu sektöründeki örgüt yönetimlerinin önemli fonksiyonu olduğu görüşünde, profesyonel nitelikteki meslek grubu üyelerinin ve kamu sektöründe çalışan ve genellikle sosyal statü bağlamında yüksek düzeyli memur statüsündeki kesimin öne çıktığı, iş̧̧i 
sınıfının ise oldukça geride kaldığı görülmektedir. Bu sonuca ilişkin olarak, halkla ilişkilerin serbest piyasaya dayalı liberal sisteme hizmet etmesi ile bağlantı kurulabilir. Bu noktada özellikle yaşam standardı ile halkla ilişkilerin önemsenmesi arasında bir bağ olduğu kanısına varılabilir.

Yukarıdaki bilgi ve yoruma paralel olarak, eğitim düzeyinin yükseldikçe halkla ilişkilerin örgüt yönetimlerinin önemli bir fonksiyonu olduğu görüşünün yaygınlaştığı görülmektedir.

Erkek katılımcıların halkla ilişkiler işlevini kadınlardan daha önemli gördüğü belirlenmiş ise de, bu farklılık çok büyük oranda gerçekleşmemiştir.

Uzun vadede halkla ilişkilerin ekonomik açıdan kazandırdığı görüşünde, gelir durumunun yüksek olması -en yüksek düzeydeki grup için- etkili olmuş; bununla birlikte iki kategoride düşük gelirli grup (asgari ücretliler; 1501-2250 TL gelire sahip olanlar), kendilerinden daha yüksek gelire sahip iki gruptan (891-1500 TL arasi gelire sahip olanlar; 2251-3000 TL arası gelire sahip olanlar) daha olumlu bir algıya sahip görünmektedir. Burada özellikle en yüksek gelir düzeyindeki grubun eğitim düzeyi, mesleki statüsü ve gelir düzeyinin bileşik olarak üst düzeyde olmasıyla halkla ilişkilerin önemli olduğu algısı arasında bir bağlantı kurulabilir.

Halkla ilişkiler çalışmalarının kurumsal imaj açısından önemsenmesi gerektiği yolundaki görüşte, sosyal statü bağlamında gelişkin konumdaki memur kesimi (akademisyen, öğretmen, doktor, polis vb.) ve profesyonel meslek grubu (avukat, mühendis, eczacı vb.) mensupları ile sosyal statü bakımından daha alt kademede yer alan işçi kesimi arasında büyük oranda bir algı farklılığı oluşması, yine halkla ilişkilerin serbest piyasaya dayalı liberal sistem içerisindeki rolünün bir yansıması olarak okunabilir.

Halkla ilişkilerin yeni iletişim teknolojileriyle birlikte öneminin arttığı yolundaki görüşlerde, öngörülenin aksine yaşın artmasıyla bir paralellik söz konusudur. 58 yaş ve üzeri katılımcıların en genç grup olan 18-27 yaş arası katılımcılardan çok daha yüksek bir ortalamaya sahip olması, genç kuşağın teknolojinin günümüzdeki kadar gelişmiş olmadığı daha önceki koşulları görmemiş olmasına bağlanabilir. Orta yaşın üzerindeki kuşaklar, bu değişimin halkla ilişkiler iletişimini çok daha güçlü konuma getirdiğini yorumlamış görünmektedirler. Buna bağlı olarak, teknolojideki değişimi deneyimlemenin halkla ilişkilerin öneminin artışını algılamada bir rol üstlendiği düşünülebilir.

Sosyal sorumluluk uygulamalarının örgütler açısından önemli bir halkla ilişkiler fonksiyonu olmasında medeni duruma göre evli katılımcıların bekârlara görece daha yüksek oranda katıldığı gözlense de, bu oran anlamlı bir farklılık göstermemiştir. Yaşam koşulları gereği, evlilerin sorumluluğa daha yatkın bireyler olduğu öngörüsünden yola çıkarak, "sosyal sorumluluk" yaklaşımına bakışlarının bekârlardan daha yoğun olduğu öngörülmüş olsa da, örgüt-toplum ilişkileri bağlamında sosyal sorumluluğun önemi dolayısıyla belirgin bir farklılaşma olmadığı düşünülebilir. Buradaki bakış açısına göre, sosyal sorumluluk, genel itibariyle kamularca önemsenen bir halkla ilişkiler uygulaması olarak kendini göstermektedir.

Halkla ilişkiler uygulamaları bağlamında Gaziantep özelinde ve Türkiye genelinde bir değerlendirme yapılması istendiğinde; katılımclların Türkiye genelindeki halkla ilişkiler çalışmalarını Gaziantep'tekilerden daha başarılı buldukları sonucuna ulaşılmaktadır. Bu durum, gerek özel sektör ve gerekse kamu sektörü için geçerlidir. Bir başka açıdan bakıldığında, veriler göz önüne getirilecek olursa, halkla ilişkilerin önemli bir fonksiyon olarak görülmesi görüşü ile 
Türkiye genelinde ve Gaziantep özelinde halkla ilişkilerin başarıyla uygulandığı görüşü arasında önemli oranda bir farklılık oluştuğu gözlenmektedir. Bu durum, kamuların algılarında halkla ilişkiler çalışmalarının Türkiye genelinde ve Gaziantep özelinde yeterli düzeyde bir başarıyı yakalayamadığı sonucuna götürmektedir. Buna göre, kamuların algılarında halkla ilişkiler işlevselliği, gerek kamu sektöründe ve gerekse özel sektörde hak ettiği değerin karşılığını bulamamaktadır (bkz. Tablo 2).

Halkla ilişkiler iletişiminde kullanılan iletişim araçlarının önemine ilişkin kamuların algılarında birinci sırayı internetin aldığı; bunun hemen ardından internet teknolojisinin türevi olan sosyal medyanın yer edindiğini görmekteyiz. Buna göre, küresel ă̆ teknolojisi, halkla ilişkiler iletişiminin başat iletişim aracl konumuna gelmiştir. Ağ teknolojisinden sonra görselliği ve işitselliği birleştiren televizyon gelmektedir. Kullanımdaki önemine göre en düşük düzeyde algılanan iletişim araçları dergi ve radyodur (bkz. Tablo 3).

Kitle iletişim araçları kullanım sıklığına göre yapılan sorgulamada, 4-6 saat arası ve 6 sat üzerinde en yoğun kullanılan iletişim aracı internet ve bunu takip eden televizyon iken, hiç kullanmama durumunda dergi ve radyo öne çıkmaktadır. Bu kategorideki sonuçlar, dikkatle bakıldığında görülecektir ki, halkla ilişkiler iletişimine yönelik Tablo 3 sonuçlarıyla birbirine paralel bir görünüm vermektedir. Ağ, kullanım yönünden katılımcıları yüksek oranlarda cezbederken, dergi ve radyo kullanımı düşük düzeyde kalmaktadır (bkz. Tablo 4).

Katılımcıların büyük çoğunluğu sosyal ağları kullandıklarını belirtmekte (bkz. Tablo 5); 4-6 saat arası ve 6 saat ve üzeri süreyle kullananların oranı 35,3 ile yüksek bir düzey yakalamaktadır (bkz. Tablo 6). Katılımcıların en çok kullandıkları sosyal medya platformunda Facebook, diğer sosyal ağ platformlarından açık ara öne çıkmaktadır. Buradaki sorgulamada Google Plus ve YouTube ilk üç sıraya yerleşerek önemli mecralar olduklarını göstermektedirler (bkz. Tablo 7). Katılımcıların ikinci en çok kullandıkları sosyal ă̆ platformu sorgulamasında, YouTube fark açarak öne çıkmakta; Twitter ve Facebook, ilk üç sıra içerisine girmektedir (bkz. Tablo 8). Katılımcıların üçüncü en çok kullandıkları sosyal ağ platformu olarak yine YouTube büyük bir farkla tercih edilmekte; bunu Google Plus ve Twitter takip etmektedir (bkz. Tablo 9). Sosyal ağ platformlarını kullanmaya dönük tüm sorgulamalar bir araya getirildiğinde; Facebook, diğer tüm sosyal ağ sitelerinden büyük bir farkla ayrılmakta; YouTube, Google Plus ve Twitter önemli oranlara ulaşmaktadır. Bu dört sosyal ağ platformunu Instagram izlemektedir (bkz. Tablo 7, Tablo 8, Tablo 9).

\section{SONUÇ VE ÖNERILER (CONCLUSION AND RECOMMENDATIONS)}

Halkla ilişkiler, stratejik iletişim uygulamaları olması yönüyle öne çıktığında, sistemler yaklaşımı perspektifinde gerçek değerini almaktadır. Açıkçası, halkla ilişkileri iletişim teknisyenliği ile sınırlandırmamak, bundan öteye stratejik bir yönetsel işlev olarak anlamlandırmak gerekir.

Halkla ilişkiler işlevselliğine yönelik kamuların perspektifini anlamak önemli görünmektedir. Bu çalışmada herhangi bir örgüt için potansiyel kamuların yönetsel bir fonksiyon olarak halkla ilişkiler uygulamalarını algılaması ön plana çıkarılmıştır.

Kamuların halkla ilişkiler kapsamındaki çalışma ve etkinliklerin örgüt yönetimlerindeki önemine ve işlevselliğine, Gaziantep'teki ve Türkiye genelindeki halkla ilişkiler çalışmalarının başarısına, halkla ilişkiler iletişiminde iletişim araçlarının önemsenmesine yönelik algıları ve kitle iletişim araçlarını ve sosyal ağ platformlarını 
kullanmaya dönük bilgileri toplamaya dayalı araştırma, bütünleşik olarak kamuların halkla ilişkiler işlevselliğine yönelik algılarını anlamaya çalışmaktadır.

Araştırmanın birinci bölümünde, halkla ilişkilerin örgüt yönetimleri açısından önemli bir fonksiyon olduğu belirlenmiş; örgüt ile kamular ve örgüt ile toplum ilişkilerinde destekleyici bir rol üstlendiği görülmüştür. Bu bölümdeki sosyo-demografik değişkenler ile anlamlılık ilişkileri sorgulanmıştır. Genel itibariyle, sosyo-ekonomik statüsü yüksek olan kamuların halkla ilişkilere yönelik algılarının daha olumlu olduğu; buna bağlı olarak, halkla ilişkilerin liberal demokrasinin koşulları ile uyumlu bir görünüm sergilediği; özellikle orta yaş üzerindeki kamuların algılarında daha yoğun olarak yeni iletişim teknolojilerinin halkla ilişkiler iletişimine güç kazandırdığı saptanmıştır.

Araştırmanın ikinci bölümünde, gerek özel sektörde ve gerekse kamu sektöründe Gaziantep'teki halkla ilişkiler çalışmalarının başarısız olduğu, Türkiye genelinde Gaziantep'e görece halkla ilişkiler çalışmalarının daha başarılı olduğu yönünde bir algı oluştuğu görülmüştür. Nitekim Türkiye'nin en büyük kuruluşlarının sıralandığı ISO-500 sıralamasında yer alan Gaziantep Organize Sanayi Bölgesindeki işletmelerin çok azında halkla ilişkiler biriminin yer alması, halkla ilişkiler işlevinin Gaziantep'te önemsenmediği gerçekliğine işaret eder. Bu açıdan, kamuların algıları, Gaziantep'te halkla ilişkiler işlevinin yeterli düzeyde yerine getirilmediğini açığa çıkarmaktadır.

Araştırmanın üçüncü bölümünde, kamuların halkla ilişkiler iletişiminde internet ve sosyal medyaya ağırlık verilmesi gerektiği görüşü ağırlık kazanmakta ve televizyonu da üçüncü önemli mecra olarak gördüğü anlaşılmaktadır. Buradan çıkarılacak sonuca göre, kamularla etkileşime geçerken halkla ilişkiler uygulamalarında kurumsal web sitelerinin, sosyal ağ platformlarının ve televizyonun ön plana çıkarılması önerilmektedir.

Araştırmanın dördüncü bölümünde, kamuların kitle iletişim araçlarını kullanmada, bir önceki bölümle örtüşen bir yapıda internet ve sosyal medyaya odaklandığı; izlenme payında televizyonun da önemli bir iletişim mecrası olarak göze çarptığı görülmektedir. Sosyal ağlar içerisinde Facebook, YouTube, Google Plus, Twitter ve Instagram adlı kanalların yüksek kullanım rakamlarına ulaştığı belirlenmiştir. Böylece gerek özel sektördeki ve gerekse kamu sektöründeki halkla ilişkiler yöneticileri, uygulayıcıları ve halkla ilişkiler ajansları yöneticileri için ağırlıklı olarak adı geçen sosyal ağlara yönelmeleri önerilmektedir.

Sonuç olarak denilebilir ki, halkla ilişkiler örgüt yönetimlerinin önemli bir fonksiyonu olması nedeniyle halkla ilişkiler uzmanları kamuların algılarını dikkate almalı ve örgüt yönetimlerine halkla ilişkiler işlevselliğinin önemini benimseterek yönetsel açıdan stratejik katkı sağlamalı; küresel ağ donatılarının yerküreyi kuşattığı günümüz koşullarında yeni iletişim teknolojileri kullanımını etkin uygulamalarla gerçekleştirmelidir. Buna ek olarak, halkla ilişkiler yöneticileri, uygulayıcıları ve akademisyenleri, halkla ilişkilere yönelik alglları daha olumlu bir düzeye getirmek için eşgüdümlü olarak çaba göstermelidirler. 


\section{KAYNAKLAR (REFERENCES)}

- Aktan, C.C. ve Börü, D., (2007). Kurumsal Sosyal sorumluluk. Kurumsal Sosyal Sorumluluk: İşletmeler Ve Sosyal Sorumluluk. (Ed. Coşkun Can Aktan), İstanbul: İĠAD Yayınları, ss:11-36.

- Becerikli, S.Y., (2005). Uluslararası Halkla İlişkiler. Ankara: Nobel Yayınları.

- Bernays, E., (1935). Molding Public Opinion. The ANNALS of the American Academy of Political and Social Science. pp: 82-87.

- Budak, G. ve Budak, G., (2010). İmaj Mühendisliği Vizyonundan Halkla İlişkiler. İzmir:Barış Yayınları Fakülteler Kitabevi.

- Çınarlı, İ., (2013). Stratejik İletişim Yönetimi. İstanbul: Beta Yayıları.

- Dozier, D.M. and Ehling, W.P., (1992). Evaluation of Public Relations Programs: What the Literature Tells Us About Their Effects. In Excellence in Public Relations and Communication Management. (Ed. James E. Grunig), Hillsdale, New Jersey: Lawrence Erlbaum Associates, pp:159-184.

- Dozier, D.M. and Grunig, L.A., (1992). The Organization of the Public Relations Function. In Excellence in Public Relations and Communication Management. (Ed. James E. Grunig), Hillsdale, New Jersey: Lawrence Erlbaum Associates, pp: 395-417.

- Ertekin, Y., (2000). Halkla İli̧̧iler. Ankara: Yargı Yayınevi.

- Geçikli, F., (1999). Süreç, Bilim, Meslek ve Sanat Olarak Halkla İlişkiler. İletişim Fakültesi Dergisi. 9, ss: 251-263.

- Görpe, S., (2001). Halkla İlişkiler Kavramları. İstanbul: İstanbul Üniversitesi ̇̇letişim Fakültesi Yayınları.

- Grunig, J.E. and Hunt, T., (1984). Managing Public Relations. Belmont CA: Thomson Wadsworth.

- Grunig, J., (1992). Communication, Public Relations, and Effective Organizations: An Overview of the Book. In Excellence in Public Relations and Communication Management. (Ed. James E. Grunig), Hillsdale, New Jersey: Lawrence Erlbaum Associates, pp: $1-28$.

- Grunig, J.E. and Grunig, L.A., (1992). Models of Public Relations and Communication. In Excellence in Public Relations and Communication Management. (Ed. James E. Grunig), Hillsdale, New Jersey: Lawrence Erlbaum Associates, pp:285-325.

- Grunig, J.E. and Repper, F.C., (1992). Strategic Management, Publics, and Issues. In Excellence in Public Relations and Communication Management. (Ed. James E. Grunig), Hillsdale, New Jersey: Lawrence Erlbaum Associates, pp:117-157.

- Grunig, L.A., Grunig, J. E., and Ehling, W., (1992). What is An Effective Organization?. In Excellence in Public Relations and Communication Management. (Ed. James E. Grunig), Hillsdale, New Jersey: Lawrence Erlbaum Associates, pp: 65-90.

- Grunig, L., (1992). How Public Relations/Communication Departments Should Adapt to the Structure and Environment of an Organization... And What They Actually Do?. In Excellence in Public Relations and Communication Management. (Ed. James E. Grunig), Hillsdale, New Jersey: Lawrence Erlbaum Associates, pp: $467-481$.

- Kalender, A., (2008). Halkla İlişkiler: Kavramlar, Tanımlar ve Uygulama Alanları. Halkla İlişkiler. (Ed. Ahmet Kalender ve Mehmet Fidan). Konya: Tablet Yayınları, ss:11-47.

- Karasar, N., (2005). Bilimsel Araştırma Yöntemi. Ankara: Nobel Yayıları. 
- Kuş, E., (2009). Nicel-Nitel Araştırma Teknikleri. Ankara: Anı Yayıncılık.

- Paksoy, A.Ç., (1999). Türkiye'deki Halkla İlişkiler Uygulamaları. İstanbul: Rota Yayınları.

- Pieczka, M., (2002). Paradigmalar, Sistemler Teorisi Ve Halkla İlişkiler. Halkla İlişkilerde Eleştirel Yaklaşımlar. (Der. Jacquie L'Etang ve Magda Pieczka), Ankara: Vadi Yayınları, ss: 215-272.

- Sabuncuoğlu, Z., (2001). İşletmelerde Halkla İlişkiler. Bursa: Ezgi Kitabevi Yayınları.

- Saylmer, İ., (2008). Sanal Ortamda Halkla İlişkiler. İstanbul: Beta Yayınları.

- Tarhan, A., (2008). Halkla İlişkiler Modelleri. Halkla İlişiler. (Ed. Ahmet Kalender ve Mehmet Fidan), Konya: Tablet Yayınları, ss:121-144.

- TÜİ, (2014). Nüfus İstatistikleri. http://www.tuik.gov.tr/UstMenu.do?metod=temelist. Erişim Tarihi: 23.11.2014.

- Ural, E.G., (2006). Stratejik Halkla İlişkiler Uygulamaları. İstanbul: Birsen Yayınevi.

- Yoldaş, Y., (2004). İşlevsel-Yapısal Sistem Kuramı. Ankara: Roma Yayıları. 